\title{
Hydrological responses of a watershed to historical land use evolution and future land use scenarios under climate change conditions
}

\author{
R. Quilbé, A. N. Rousseau, J.-S. Moquet, S. Savary, S. Ricard, and M. S. Garbouj \\ Institut National de la Recherche Scientifique - Centre Eau, Terre et Environnement (INRS-ETE), Université du Québec, 490 \\ rue de la Couronne, Québec (QC), Canada, G1K 9A9
}

Received: 22 March 2007 - Published in Hydrol. Earth Syst. Sci. Discuss.: 5 June 2007

Revised: 1 October 2007 - Accepted: 10 December 2007 - Published: 25 January 2008

\begin{abstract}
Watershed runoff is closely related to land use but this influence is difficult to quantify. This study focused on the Chaudière River watershed (Québec, Canada) and had two objectives: (i) to quantify the influence of historical agricultural land use evolution on watershed runoff; and (ii) to assess the effect of future land use evolution scenarios under climate change conditions (CC). To achieve this, we used the integrated modeling system GIBSI. Past land use evolution was constructed using satellite images that were integrated into GIBSI. The general trend was an increase of agricultural land in the 80 's, a slight decrease in the beginning of the 90 's and a steady state over the last ten years. Simulations showed strong correlations between land use evolution and water discharge at the watershed outlet. For the prospective approach, we first assessed the effect of CC and then defined two opposite land use evolution scenarios for the horizon 2025 based on two different trends: agriculture intensification and sustainable development. Simulations led to a wide range of results depending on the climatologic models and gas emission scenarios considered, varying from a decrease to an increase of annual and monthly water discharge. In this context, the two land use scenarios induced opposite effects on water discharge and low flow sequences, especially during the growing season. However, due to the large uncertainty linked to CC simulations, it is difficult to conclude that one land use scenario provides a better adaptation to CC than another. Nevertheless, this study shows that land use is a key factor that has to be taken into account when predicting potential future hydrological responses of a watershed.
\end{abstract}

Correspondence to: A. N. Rousseau

(alain.rousseau@ete.inrs.ca)

\section{Introduction}

Runoff and water quality are influenced by many natural and anthropogenic factors that occur at the watershed scale. It is well known that land use constitutes one of these factors, and that deforestation of one piece of land for agricultural or urban development can affect locally water balance and pollutant fate. This influence of land use is difficult to quantify, especially over the long term and at large scale such as that of a regional watershed where complex interactions occur. Recent developments of decision support systems based on geographic information systems (GIS) and distributed hydrological models have provided practical and useful tools to achieve this goal (Fohrer et al., 2001). All the studies based on such models show that deforestation for agricultural land or urbanisation induces an increase in water discharge and peak flow, but with various intensities. For instance, Costa et al. (2003) showed that increase of agricultural land from $30 \%$ to $49 \%$ of the Tocatins River watershed (Brazil, $767000 \mathrm{~km}^{2}$ ) led to a $24 \%$ increase of the mean annual water discharge. On the other hand, Fohrer et al. (2001) found only a moderate effect of land use changes on the annual water balance of the small Dietzhölze watershed (Germany, $82 \mathrm{~km}^{2}$ ). Moreover, Dunn and MacKay (1995) showed, using the distributed SHETRAN model, that land use change has more influence on lowland subwatersheds than on highland subwatersheds. Thus, the intensity of the effect of land use on water regime depends on the size, the slope and land use characteristics of the watershed (see also CognardPlancq et al., 2001; Matheussen et al., 2000). Obviously, it also depends on the hydrological model used and the physical processes simulated. Note that it is also possible to use decision support systems based on GIS and distributed hydrological models to define an optimal land use change that would enable to achieve a specific objective such as reducing peak flow or nonpoint source pollution (Yeo et al., 2004).

Published by Copernicus Publications on behalf of the European Geosciences Union. 


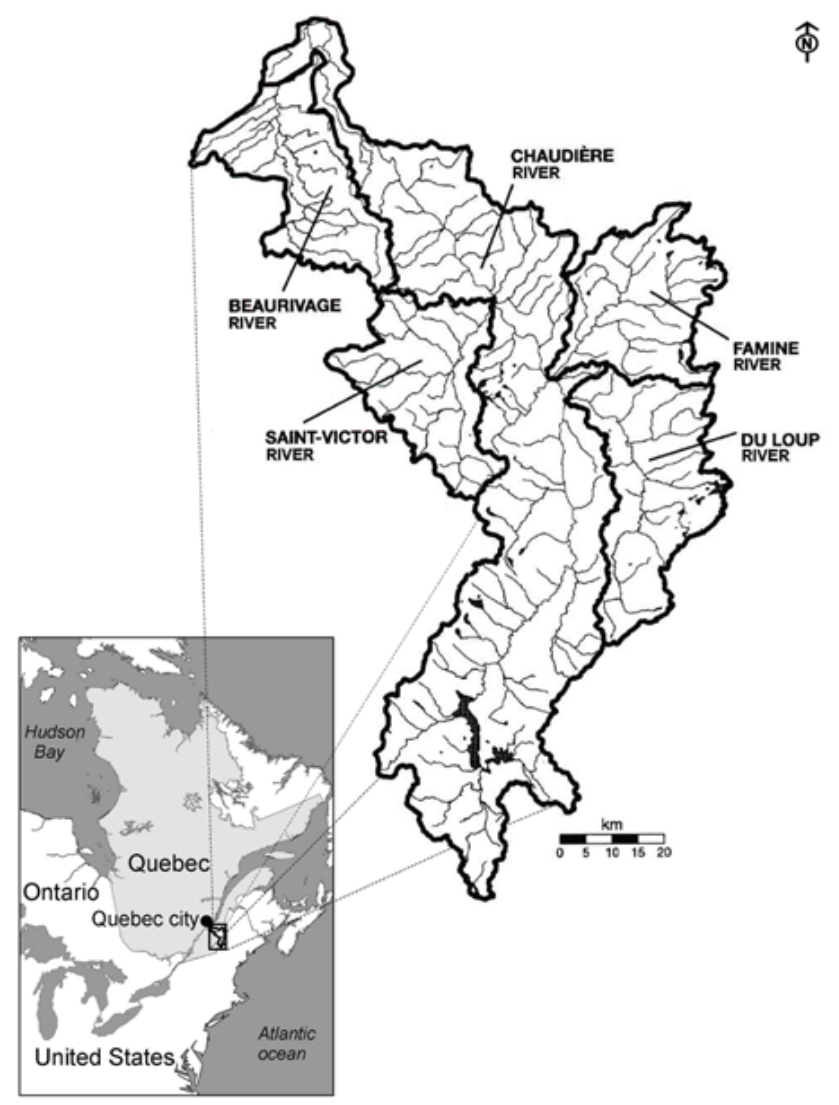

Fig. 1. The Chaudière River watershed.

Assessment of land use effect on hydrology is of special interest regarding the expected climate changes (CC). Indeed, most of the studies that have tried to forecast the effect of CC on hydrology and water quality consider that the watershed configuration would stay the same in the future as today (for instance Wood and Maurer, 2002). However, it is likely that land use will continue to evolve over the next decades, notably as an adaptation to $\mathrm{CC}$ and to regional and world economies, and that it will have an important influence on future watershed hydrology (Kite, 1993).

In this study, we used the integrated modeling system GIBSI (see description below) to assess the effect of agricultural land use on the hydrology of the Chaudière River watershed (Québec, Canada), both under past and future conditions. Indeed, it is important to understand what happened in the past before trying to assess what would be the role and influence of both CC and land use evolution on future watershed hydrology (Crooks and Davies, 2001). Note that GIBSI has already been used to assess the effect of clear cutting on watershed hydrology (Lavigne et al., 2004) leading to consistent results. The first part of this study consists in determining the land use changes over the Chaudière River watershed between years 1970 and 2003 using remote sensing. The resulting land use maps will be compared and finally introduced in the geographic database of GIBSI to assess the impact of land use evolution on hydrological regime. Then, the second part of the study focuses on defining land use evolution scenarios and simulating their influence on hydrology under future climatic conditions.

\section{GIBSI}

GIBSI is an integrated modelling system designed to assist stakeholders in decision making process for water management at the watershed scale (Rousseau et al., 2000; Villeneuve et al., 1998). It is basically composed of a MySQL® database management server, a GIS and a graphical user interface (GUI). The modeling part is based on the semidistributed, physically based hydrological model HYDROTEL (Fortin et al., 2001a). HYDROTEL integrates six computational modules that are run in a cascade (i.e. in a decoupled manner): weather data interpolation, snow cover dynamic, potential evapotranspiration, soil moisture balance, surface runoff and streamflow. Each module offers more than one computational algorithm based on the availability of data for the studied watershed. Some algorithms, developed from physically based principles, retain some empirical aspects while others are still fully empirical. Rainfall-runoff processes can be modeled on a 3-24-h time step basis. The hydrological model is sensitive to land use configuration by the mean of the Manning coefficient (for surface runoff routing), leaf area index and root depth (for actual evapotranspiration calculation). Other models can be used (i.e. erosion, nitrogen, phosphorus and pathogens transport), but they were not considered in this study. All models run on a daily time step with meteorological data (precipitation, minimum and maximum temperatures) as inputs. Outputs are daily streamflow and water quality data at any computational river segment. Pre- and post-processing tools enable to easily define management scenarios, run simulations and analyse results. The 1995 land use configuration is used by default in the database and for simulations. It was determined based on a satellite image processed and validated with 1994 survey data (Villeneuve et al., 1998).

\section{The Chaudière River watershed}

The Chaudière River watershed is located south of Quebec City and covers an area of $6682 \mathrm{~km}^{2}$ (Fig. 1). It was selected because it is representative of many watersheds of the SaintLawrence River valley, with various land uses: $63 \%$ forest, $17 \%$ agricultural land, $15 \%$ bush, $3 \%$ urban development and $2 \%$ surface water. Soils vary from loam in the upper part of the watershed to clay loam in the middle part and loamy sand in the lower part. Agriculture is dominated by animal production, especially pig and dairy farming. This implies that most of farmed lands are forages and pasture $(75 \%$ of agricultural land in 1995). The population of the watershed 
Table 1. Satellite images used for the characterisation of land use evolution on the Chaudière River watershed.

\begin{tabular}{ll}
\hline Acquisition date & Satellite and Sensor \\
\hline 4 Sep 1976 & Landsat-2 MSS \\
14 Sep 1981 & Landsat-2 MSS \\
6 Sep 1987 & Landsat-5 TM \\
29 July 1990 & Landsat-5 TM \\
28 Aug 1995 & Landsat-5 TM \\
14 July 1999 & Landsat-7 ETM+ \\
2 Sep 2003 & Landsat-5 TM+ \\
\hline
\end{tabular}

is around 180000 inhabitants. For the application of GIBSI, the study watershed was subdivided into 1870 elementary basins or spatial simulation units (SSUs, with a mean area of $\left.3.6 \pm 1.9 \mathrm{~km}^{2}\right), 10$ lakes $\left(5.6 \pm 8.3 \mathrm{~km}^{2}\right), 1799$ river segments $(1.9 \pm 1.2 \mathrm{~km})$, and 46 lake segments $(1.5 \pm 4.4 \mathrm{~km})$. Calibration of the hydrological model HYDROTEL was performed on the whole watershed considering measured and simulated streamflows (for details, see Fortin et al., 2001b). The model efficiency was satisfactory regarding streamflow at the outlet of the watershed with Nash-Sutcliffe (NS) coefficients of 0.88 and 0.83 for $1989-1990$ and $1993-1994$, respectively. A temporal validation was performed on 1987-1988 and 19901991 (NS=0.83 for both periods) as well as over a 10-year period $(\mathrm{NS}=0.89$ ). A spatial validation was also performed for the Famine and Beaurivage subwatersheds with similar results (NS between 0.78 and 0.88 ). Additionally, snow survey data were compared to water-equivalent depths of the simulated snowpack for several stations, showing that snow accumulation and snowmelt were well simulated by the model. Several management-oriented applications of GIBSI on the Chaudière River watershed have been performed over the last ten years and are described by Quilbé and Rousseau (2007).

\section{Data and methods}

\subsection{Effect of historical land use evolution}

\subsubsection{Past land use evolution reconstruction}

This part of this study is described in details by Savary et al. $(2008)^{1}$. Identification of land use evolution was based on seven Landsat satellite images acquired over the 1970-2003 period (Table 1). Their selection was based on several criteria such as the period of the year (summer period is better

${ }^{1}$ Savary, S., Rousseau, A.N. and Quilbé, R. : Assessing the impact of past land use changes on runoff and low flows using remote sensing and distributed hydrological modeling - a case study for the Chaudière River watershed (Quebec, Canada), in preparation, 2008.
Table 2. Land use classes used in GIBSI.

\begin{tabular}{ll}
\hline Class number & Land Use classes \\
\hline 1 & Urban \\
2 & Pasture \\
3 & Cereals \\
4 & Corn \\
5 & Water \\
6 & Wetland \\
7 & Bare Soil \\
8 & Shrub land \\
9 & Deciduous Forest \\
10 & Evergreen Forest \\
\hline
\end{tabular}

for crop identification) and watershed cover. The image processing methodology includes three steps: pre-processing, classification and analysis. Pre-processing operations are essential for exploiting satellite products and allowing the analyst to work within a geo-referenced environment and to restore image quality. They include radiometric and geometric transformations, as well as image resizing for the watershed area. Classification started with the identification of clouds and water classes using mask application. Then, a supervised object-oriented classification was performed using eCognition (Definens Imaging, 2001) which considers not only pixel spectral characteristics but also forms, textures and neighbourhood notions. As field land use knowledge was not available, training site definition was mainly supported by visual image interpretation and previous studies on the Chaudière River watershed (Dolbec et al., 2005; Gauthier, 1996). Finally, correction of unclassified regions was made using the nearest date class availability. The resulted land use classes are presented in Table 2.

\subsubsection{Effect on hydrology}

The classified images were integrated into GIBSI by automatic updating of the relevant land use tables of the database. For each land use configuration, simulations were run using measured meteorological sequences over 30 y (1970-1999) as input, each year being simulated independently. This ensures that the results are representative of a wide range of meteorological conditions and that the differences obtained are only due to the differences in land use. Results include daily streamflow series at any computational river segment of the Chaudière River watershed. We checked the effect at the watershed outlet as it integrates the effect of both land use evolution and climate change over the whole watershed.

\subsection{Effect of future land use evolution}

This prospective approach had to take into account not only potential evolution of land use in a near future, but also the 


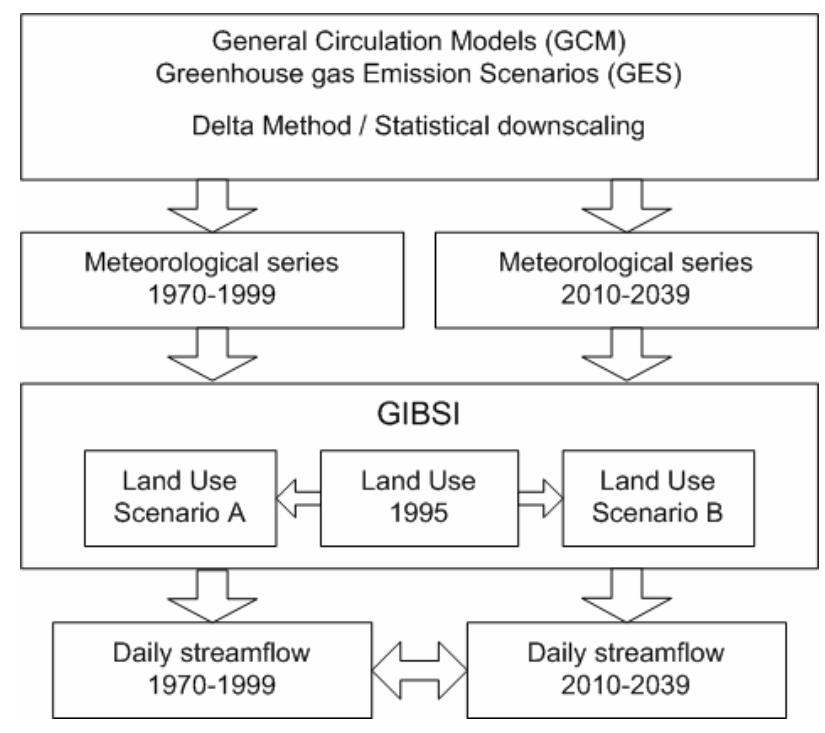

Fig. 2. General approach used to assess the effect of $\mathrm{CC}$ and land use evolution scenarios on hydrology.

evolution of climate. The time interval considered in this study is $30 \mathrm{y}$, the reference period being from 1970 to 1999 and the future period from 2010 to 2039 . The choice of a short term prediction implies that modeled changes in watershed hydrology will be slight but avoids a too important uncertainty in climate change and especially agricultural evolution prediction. It reflects the difficulty to determine longterm agricultural land use and world market scenarios. As stated by Butcher (1999), it is impossible to develop realistic land use projections for a period of more than 20 to $30 \mathrm{y}$. The general approach is depicted on Fig. 2.

\subsubsection{Determination of future meteorological series}

The meteorological variables that have to be determined for the future period are the input variables of the semidistributed hydrological model HYDROTEL which are daily minimum temperature (TMIN), maximum temperature (TMAX) and precipitation $(P)$. Several methods exist, the most popular being the use of General Circulation Models (GCMs) based on greenhouse gas emission scenarios (GES). GCMs accurately predict climatic variables such as wind and temperature at a large scale. However, hydrology depends on meteorological variables such as precipitation, minimum and maximum temperatures or evapotranspiration, at the land surface level and at fine spatial and temporal scales $(\mathrm{Xu}, 1999)$. To fill this gap and determine future local meteorological sequences from GCM output, we used two methods: (1) delta (or incremental) method and (2) statistical downscaling (SD). Delta method is simply based on the calculation of a monthly deviation between GCM outputs for future and present periods. SD method is more sophisticated. The idea here is to link regional-scale climatic
Table 3. GCMs-GES-M combinations used with the two methods for determining future meteorological series.

\begin{tabular}{lccccc}
\hline GCM & GES & Member & Method 1 & Method 2 & Method 3 \\
\hline CGCM3 & A2 & 1 & x & & \\
& & 2 & & & \\
& & 3 & & & \\
& B1 & 1 & & & \\
& & 2 & & & \\
HadCM3 & A2 & a & x & x & x \\
& & b & x & & \\
& & c & & & x \\
& B2 & a & x & x & \\
ECHAM4 & A2 & b & & & \\
& B2 & - & x & & \\
\hline
\end{tabular}

variables (so-called predictors) to local meteorological variables (so-called predictands, here surface temperature and precipitation) by regression, and then to calculate future daily values of predictands based on future GCM outputs for predictors. Note that a third method combining the delta method with the downscaled data was also used for comparison purposes, but results will not be presented here (see Quilbé et al. (2008) for details about these three methods). For the delta method, several GCMs and GESs were available. We selected the three GCMs that gave the best results as compared to measured data over the reference period: (i) the third version of the Coupled General Circulation Model (CGCM3) from the Canadian Centre for Climate Modelling and Analysis - this version is based on CGCM2 (Flato et al., 2000) and incorporates a new version of the atmospheric component as described by Scinocca and McFarlane (2004); (ii) the third version of the Hadley Centre for Climate Prediction and Research model HadCM3 (Johns et al., 2001); and (iii) the Max Planck Institute for Meteorology model ECHAM4 (Roeckner et al., 1996). Several GESs can be considered for each GCM, as reported in the Special Report on Emission Scenarios (SRES). Basically, scenarios of families A2 and B2 correspond to pessimistic and optimistic GES, respectively. For each scenario family, several simulation members (M) are available and characterized by different initial conditions (for instance A2-a \& A2-b). We selected the GES-M combinations that gave the largest range of future meteorological conditions (see Table 3). For the SD method, the only available GCM was HadCM3, based on two GESs (see Table 3). The SD procedure was performed using SDSM (Wilby et al., 2002) for nine meteorological stations out of the 40 available stations. More details about methods and results are given by Quilbé et al. (2008). 

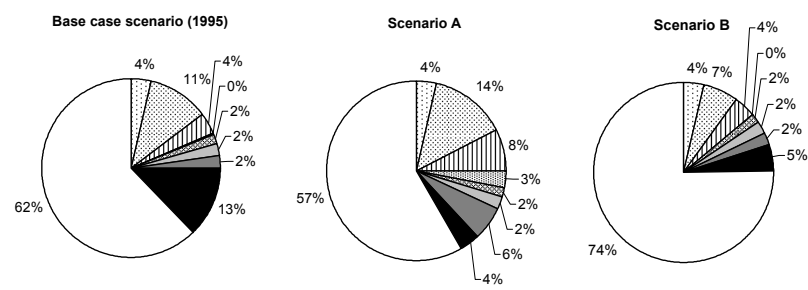

国 Urban 圈 Pasture 血 Cereals 圆 Corn 圆 Water $\square$ Wetland $\square$ Bare soil

Fig. 3. Distribution of land use on the watershed for base case scenario, Scenario A and Scenario B.

\subsubsection{Land use evolution scenarios}

The base case scenario regarding land use was the 1995 configuration. Then, two opposite scenarios of future land use evolution were defined to represent a wide range of possible configurations, scenarios A and B.

- Scenario A was based on the assumption that pig production will remain the priority incentive of agricultural development in the region. Thus, the evolution of pig production over the last $30 \mathrm{y}$ was extrapolated to the next $20 \mathrm{y}$, from 89739 animal units in 1995 to 136370 animal units in 2025 ( 1 animal unit corresponds to 30.3 pigs). As a consequence of this increase, land use was adjusted. Indeed, increased pig production implies conversion of more agricultural land for pig food production (that is grain corn) and manure spreading, to the detriment of cereals, pasture, shrub land and forest areas. Three land use classes were found to be correlated with pig production over the past 30 years: corn $(r=0.76)$, pasture $(r=0.79)$ and forest $(r=-0.77)$. Then, the future class areas were extrapolated based on regression curves and future pig production.

- Scenario B was based on the assumption that agriculture will make a radical change and come back to the land use configuration of 1976, with reforestation to the detriment of shrub land and pasture. This scenario also considered a spatial dispersion of corn and cereal lands over the whole watershed.

For both scenarios, the shrub land class is used as a buffer class to implement deforestation or reforestation. For scenario A, we make the assumption that, as most of these lands were farmed in the 70s, they are the most likely to be farmed again. Thus, new corn fields replaced shrub land and then forest area when there is no more shrub land. For scenario B, we considered that these lands will naturally transform into young forests. Note that urban area is considered to stay the same as today. These changes were integrated into GIBSI using the land use management GUI. One limitation of this system is that, for a given spatial management unit (watershed, subwatershed, municipality or SSU), every change in

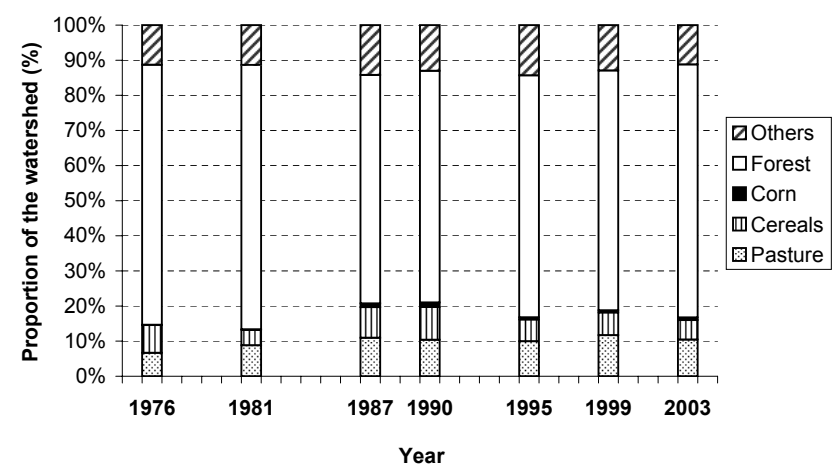

Fig. 4. Evolution of agricultural and forest land use on the Chaudière River watershed over the past $30 \mathrm{y}$.

land use is done by a complete transfer of one class to another. Therefore, we made a calculated number of transfers on different SSUs (for example all forest transformed into shrub land on one SSU, and all pasture transformed into corn on another SSU) so that the overall proportions are respected at the watershed scale. The corresponding land use distributions are depicted on Fig. 3.

Note that this procedure presents some subjectivity, especially in the case of scenario A. However, what is important is the general tendency at the watershed scale and the results should be considered as possible tendencies with respect to the 1995 base conditions and not be interpreted in a quantitative way.

\subsubsection{Effect on hydrology}

As indicated on Fig. 2, GIBSI simulations were performed over 30 years with original meteorological sequences (19701999) and with modified (i.e. future) sequences (20102039). As for the retrospective approach, each year was simulated independently. This was done for each land use configuration (reference, scenario A and scenario B). Comparisons between present and future watershed hydrology were made with respect to mean annual, seasonal and monthly water discharge (i.e. total runoff). In order to see the effect of CC and land use evolution on low-flow events, a frequency analysis was performed using HYFRAN@ software (Chaire en hydrologie statistique, 2002). We determined critical streamflow sequences over seven and thirty consecutive days. These were $Q_{2-7}, Q_{10-7}$ and $Q_{5-30}$ corresponding to return periods of two, ten and five years, respectively. These variables were chosen because they are used in the context of wastewater loads legislation in North America (for $Q_{2-7}$ and $Q_{10-7}$ ) and in Europe (for $Q_{5-30}$ ). We also considered the spring peak flow. It should be noted that, by using the models under $\mathrm{CC}$ conditions, we may not be in the calibration domain any more. Thus, we made the assumption that the calibration parameter set remained optimal (Drogue et al., 2004). 


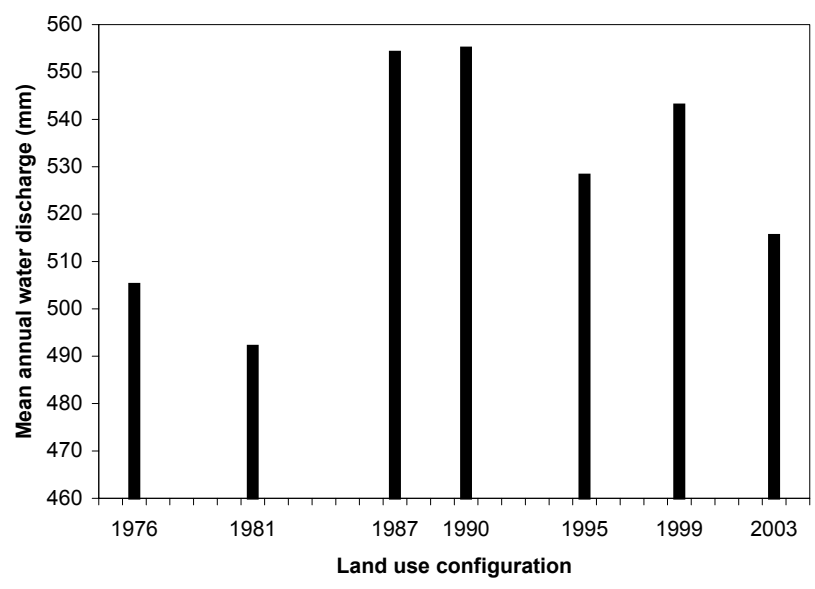

Fig. 5. Evolution of the mean annual water discharge at the outlet of the Chaudière River watershed simulated with GIBSI as a function of land use configuration.

\section{Results}

\subsection{Effect of historical land use evolution}

Figure 4 presents the temporal evolution of land use over the Chaudière River watershed. We can see that the agricultural land class is characterised by fluctuations attributed to the cereal class variability, while pasture area is steadier. These fluctuations of agricultural land are inversely correlated to forest evolution. This is due to the fact that new agricultural lands are mostly taken from shrub lands (shrub is included in the forest class), while shrub replaces agricultural lands when neglected. The mean annual runoff, simulated with GIBSI and based on 30-year meteorological series, was also found to be strongly correlated with agricultural land $\left(r^{2}=0.97\right)$, with a minimum of $492 \mathrm{~mm}$ for the 1981 land use configuration and a maximum of $555 \mathrm{~mm}$ for the 1990 land use configuration (see Fig. 5), and a coefficient of variation $\left(c_{v}\right)$ of $4.6 \%$. Note also that the effect of land use on water discharge is statistically significant $(p<0.001$, Friedmann test). It should also be noted that this effect of agricultural land on annual runoff is homogeneous over the thirty years of simulations, meaning that the relative effect is stronger for dry years. It is also important to note that this effect is more important from June to November, while there is no effect in winter and spring. Indeed, in the latter period, runoff occurs mostly under saturated soil conditions. Since evapotranspiration is then negligible it means that the kind of vegetation (i.e. crop type vs. forest) does not influence water balance during this period (winter and early spring). Besides, the mean spring peak flow, although correlated to land use, does not vary a lot (minimum of $1309 \mathrm{~m}^{3} / \mathrm{s}$ with the 1981 land use configuration, maximum of $1337 \mathrm{~m}^{3} / \mathrm{s}$ with the 1999 land use configuration, $\left.c_{v}=0.8 \%, p<0.001\right)$. On the other hand, in summer and fall, runoff is mainly due to strong rainfall

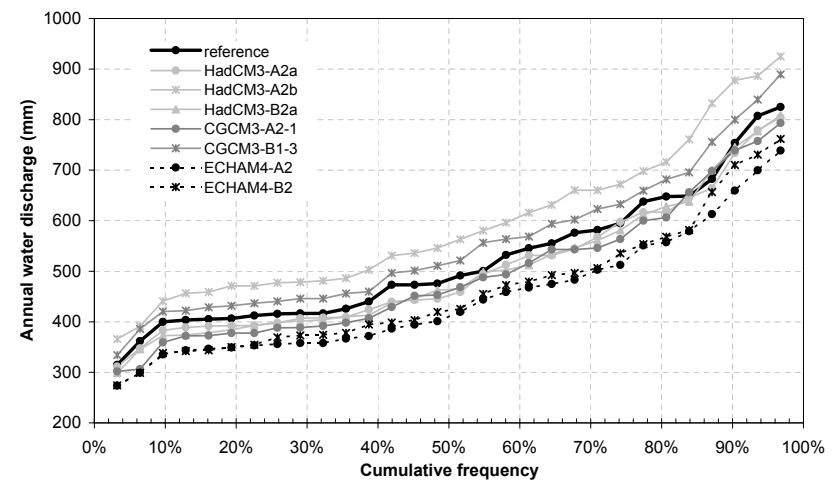

Fig. 6. Effect of CC on annual water discharge at the outlet of the Chaudière River watershed using the delta method and the different GCM-GES-M combinations used in this study.

events, thus dense vegetation cover such as forest makes a big difference as compared to farmed land regarding rain interception, evapotranspiration and, consequently, runoff generation. For these reasons, good correlations were also found between agricultural land and summer low flow sequences as obtained with the frequency analysis, with determination coefficients of $0.95,0.93$ and 0.93 , respectively, for $Q_{2-7}$, $Q_{10-7}$ and $Q_{5-30}$. These results confirm that the hydrological regime of the Chaudière River watershed is highly sensitive to land use.

5.2 Effect of future land use evolution under climate change

\subsubsection{Effect of climate change}

First, we assessed the effect of future CC on water discharge, the other factors being equal - that is considering that no change occurs in land use (i.e. 1995 configuration; that is the reference land use). Simulation results obtained with the future meteorological sequences were compared to those performed with the meteorological sequences for the reference period (measured data for delta method or simulated data for SD). Figure 6 shows the annual water discharge obtained with the delta method (delta) using the thirty years of historical and future meteorological data. We can see an important dispersion depending on the GCM-GES-M combination used. Indeed, we obtained an increase in annual water discharge for two combinations (HadCM3-A2b, CGCM3B1-3) and a decrease for the others, especially when using ECHAM4-A2 and ECHAM4-B2. Since no GCM-GES-M combination can be determined as better than the others, this wide dispersion makes it difficult to conclude about the effect of CC on annual water discharge. One possibility is to assume all GCM-GES-M combinations as equiprobable. Then, the mean trend is a slight decrease of annual discharge (mean of $-2.7 \%$ ) which is statistically significant $(p<0.01$ with a paired $t$-test). However, the meaning of such interpretation 


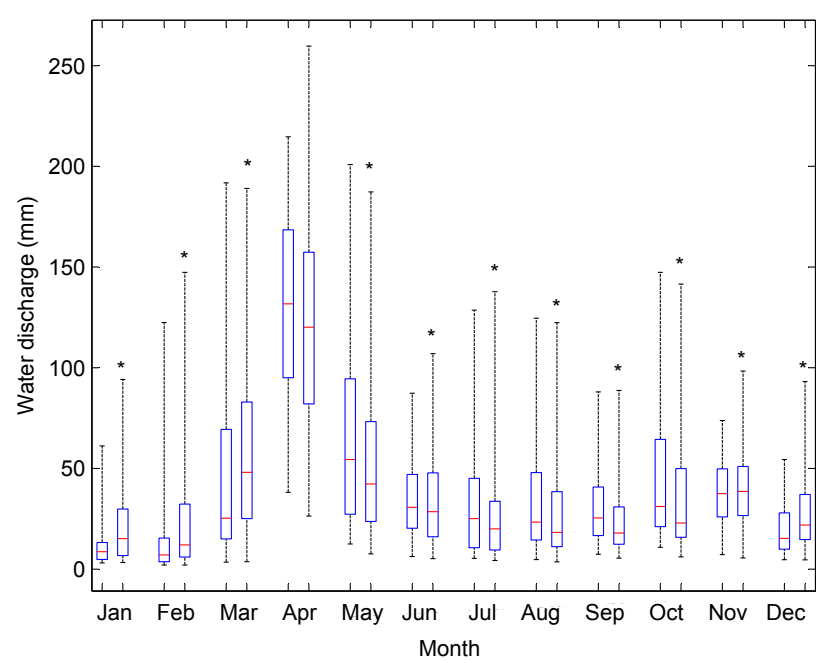

Fig. 7. Monthly water discharge as simulated for reference period (left box plots) and future period with all GCM-GES-M combinations considered as equiprobable (right box plots). Central line indicates the median value, box-plot limits indicate 1st and 3rd quartiles, and bars indicate maximum and minimum values. Stars indicate that the means are statistically different (paired $t$-test, $p<0.05)$.

remains impossible to cast without a doubt and should be considered with caution. At the monthly time step (Fig. 7), the only effects that are observed for all GCM-GES-M combinations were an increase in water discharge in winter (December to February) and a decrease in May and October. This is in all likelihood due to the higher temperatures predicted by GCMs in winter that induce less snow, more rain, and an earlier snowmelt, as well as more evapotranspiration during summer. For the other months, the effect of CC varies from one GCM-GES-M combination to another so that no general conclusion can be given, even if the means are generally statistically different.

Regarding daily streamflow, results obtained with the SD method are probably more realistic than those from the delta method as the former accounts for a change in precipitation frequency and intensity while the latter does not (for a detailed discussion see Quilbé et al., 2008). Unfortunately, only one GCM (HadCM3) could be considered. The results show a decrease in spring peakflow for HadCM3-A2a $(-3.8 \%$ for the mean over the thirty years, not significant) and for HadCM3-B2a $(-12.9 \%, p<0.05)$, due to warmer temperatures in winter and earlier snowmelt. Finally, regarding summer low flows, results are heterogeneous. The HadCM3-A2a combination induced a strong increase in $Q_{2-7}$ but a decrease in $Q_{5-30}$ and $Q_{10-30}$, while HadCM3-B2a induced an increase of all sequences. It is surprising to see that the latter had a stronger effect than the former on peak flow, as GES B2 was supposed to be more optimistic regarding greenhouse gases emissions than GES A2. Actually, the difference
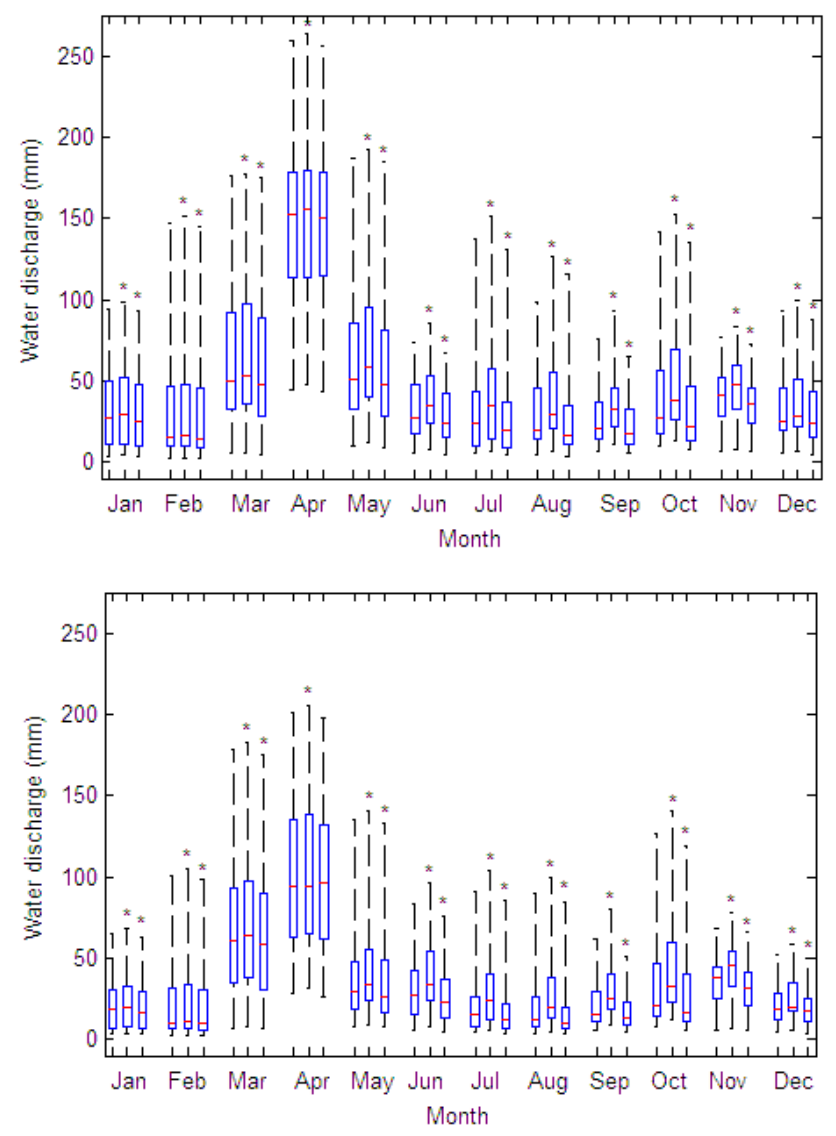

Fig. 8. Effect of land use scenarios A (middle box) and B (right box) on monthly water discharge as compared to reference land use (left box) obtained from GIBSI simulations, Delta method and two GCM-GES-M combinations (HadCM3-A2b upper graph and ECHAM4-B2 lower graph). Central line indicates the median value, box-plot limits indicate 1 st and 3rd quartiles, and bars indicate maximum and minimum values. Stars indicate that the means are statistically different (paired $t$-test, $\mathrm{p}<0.05$ )

between HadCM2-A2a and HadCM2-B2a is not only linked to the GES but also to different initial conditions in GES simulations. Even TMIN, TMAX and $P$ results for reference period are different for both GCM-GES-M combinations. This indicates that, at such a short term (2025), the different GESGCM-M combinations should be seen as different, equiprobable simulations rather than as pessimistic or optimistic conditions.

\subsubsection{Effects of land use evolution scenarios}

The previous results only accounted for the effect of CC without any change in watershed configuration. The next step was to simulate the effect of the two land use evolution scenarios under these CC conditions. Regarding the delta method, we considered here only the two GCM-GES-M combinations that gave the extreme effect on 

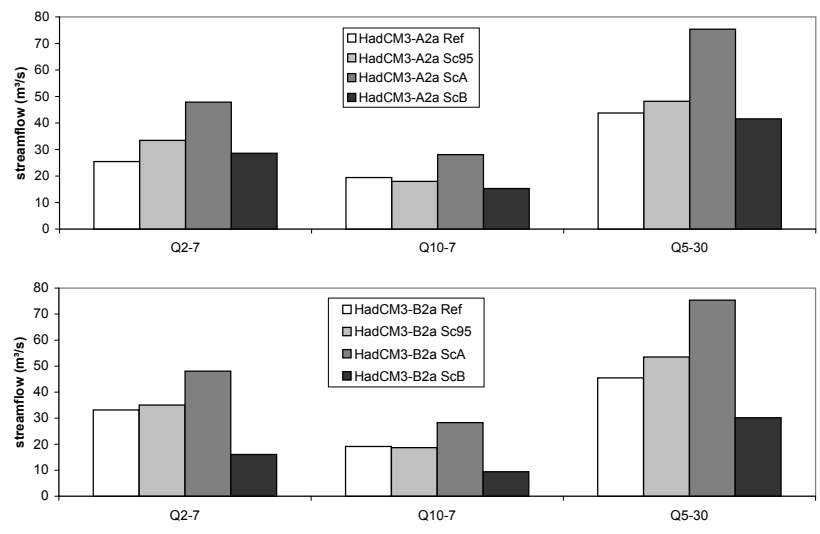

Fig. 9. Effect of $\mathrm{CC}$ (Sc95 vs. ref) and land use evolution scenarios ( $\mathrm{ScA}$ and $\mathrm{ScB}$ vs. Sc95) on low flow statistical sequences $\left(\mathrm{m}^{3} / \mathrm{s}\right)$ obtained with downscaling method and the two GCM-GESM used : HadCM3-A2a (upper graph) and HadCM3-B2a (lower graph). "ref" is the reference simulation (reference period 19701999), "Sc95" stands for the future period simulation (2010-2039) considering climate change but no evolution in land use (i.e. 1995 land use) and "ScA" and "ScB" stand for the future simulations considering the land use scenarios $\mathrm{A}$ and $\mathrm{B}$, respectively, in addition to climate change.

water discharge, i.e. ECHAM4-B2 and HadCM3-A2b, as they represent the whole range of possible future conditions (see Fig. 6). The results are depicted on Fig. 8 and show that, in both cases, Scenario A would induce an important increase of water discharge from May to November, while Scenario B would induce a slight decrease over the same period. Regarding annual runoff, the effect would be $+13.6 \%$ $(p<0.001)$ and $-7.2 \%(p<0.001)$, for Scenarios A and B, respectively (considering the two GCM-GES-M as equiprobable). As shown in the first part of this study, these results are due to the strong correlation between agricultural land area and water discharge. As Scenario A includes an increase in agricultural land to the detriment of shrub land and forest, this implies an increase in runoff over the watershed in spring and fall. It is the opposite effect for Scenario B. Similar behaviour was found regarding low flow sequences with the SD method, with an increase for Scenario A and a decrease for Scenario B. We can see on Fig. 9 that the single effect of $\mathrm{CC}$ on low flow sequences without any land use change (see Sc95 vs. Ref on Fig. 9) is low as compared to the effect of land use scenario A (see ScA vs. Sc95) and even scenario B for HadCM3-B2a (see ScB vs. Sc95). Note that these results are obtained from only one GCM and that other GCMs may lead to a different pattern, although it was not possible to do test these hypothesis given available data (for a complete discussion regarding this methodological constraint see Quilbé et al., 2008).

It is important to keep in mind that important uncertainty and many assumptions are linked to the methodological approach that was used to determine the future meteorological sequences. For instance, the use of different methods (delta versus statistical downscaling) and different data sets (i.e. GCM-GES-M combinations) led to a wide range of results, some of them being contradictory. Moreover, the intensity of extreme meteorological events are not well predicted by those methods, even statistical downscaling (Gachon et al., 2005), so that the effect on peak flow and low flow are also tainted with uncertainty. Furthermore, the hydrological model calibration was performed for a specific time period and land use configuration, and we have to make the assumption that the resulting calibration parameter set remains optimal under future climate and land use conditions. Finally, important factors are not taken into account by this approach, such as potential implementation of irrigation. Consequently, it is difficult to conclude that one land use evolution scenario would be better than another under $\mathrm{CC}$ conditions. Bouraoui et al. (1998) performed the same kind of approach with the ANSWERS model to assess the expected effects of long term $\mathrm{CC}$ (doubling of $\mathrm{CO}_{2}$ ) and land use management scenarios on the water balance, particularly drainage below the crop root zone. They could show that CC will induce a decrease of groundwater recharge and that this effect will be much smaller with alternative techniques such as winter wheat and/or alfalfa.

In our case, the results did not converge towards one general conclusion regarding the effect of $\mathrm{CC}$ on water discharge due to the large uncertainty, but they confirm the necessity to consider several sources of data. For instance, if one would have used only HadCM3-A2b to generate future meteorological sequences, he would have concluded to a strong increase of annual water discharge, while most of the other GCMGES-M combinations predict the opposite effect. This uncertainty is also problematic from a management point of view. In this way, a difficult but challenging step is for scientists to communicate the results of such impact studies to stakeholders so that mitigation measures can be determined (see Fowler et al., 2007). Indeed, stakeholders need to know what will be the impact, at least a trend, so that they can make decisions and undertake mitigation and adaptation actions. What can be done when simulations give a wide range of possibilities, as it is the case here? In this regard, the quantification of uncertainty and a probabilistic risk assessment approach would be needed. Moreover, stakeholders also have to consider what is desirable regarding water uses. In this regard, the effect of CC and land use scenarios on pollutant loads and water quality has also to be considered as it was shown that some land use changes drastically affect many water quality parameters (Tong and Chen, 2002; Wilby et al., 2006).

In order to reduce uncertainty, further work should also use more confident techniques such as dynamical downscaling based on Regional Climate Models (for a complete overview of this modelling approach see Laprise, 2006), to predict the effect of CC in perhaps a more reliable way. However, a remaining major problem in such studies is that, on one hand, the assessment of CC effect on hydrology has to consider 
a long term trend (at least 2050 horizon) to produce an effect that is strong enough to be clearly related to $\mathrm{CC}$ and not to GCMs output variability, while on the other hand, realistic land use evolution scenarios can only be determined at short term because of unpredictable trend in world markets (Butcher, 1999).

\section{Conclusions}

The first part of this study clearly shows the strong effect that land use, and especially agricultural land use, had on the hydrological regime of the Chaudière River watershed between 1970 and 1999. Therefore, as illustrated in the second part of this study, it is of major importance to take into account possible future land use evolution when forecasting the behaviour of a watershed within a CC context (Pielke, 2005). Yet, due to the uncertainty linked to the prediction of CC effect, it is difficult to conclude about the mitigation effect of the two opposite future land use scenarios considered in this study. However, they induce an effect that is in the same order of magnitude as - and even, in most cases, stronger than $\mathrm{CC}$ on the water regime of the Chaudière River during growing season, confirming that land use will be a key factor in adaptation to $\mathrm{CC}$.

Acknowledgements. This research was partly funded by a grant from the Climate Change Action Fund (Natural Resources Canada, grant A946) and by OURANOS (Consortium on regional climatology and adaptation to climate change) (A. N. Rousseau, principal investigator). We wish to thank Sébastien Tremblay (INRS-ETE) for precious computing help, as well as Philippe Gachon, Yonas Dibike, Nathalie Gauthier and Diane Chaumont (OURANOS) for helpful discussions and providing data.

Edited by: A. Ducharne

Reviewed by: anonymous referees

\section{References}

Arnold, J. G. and Williams, J. R.: SWRRB - A watershed scale model for soil and water resources management, in: Computer Models of Watershed Hydrology, edited by: Singh, V. P., Water Resources Publication, Highlands ranch, 847-908, 1995.

Bouraoui, F., Vachaud, G., and Chen, T.: Prediction of the effect of climatic changes and land use management on water resources, Phys. Chem. Earth, 23(4), 379-384, 1998.

Butcher, J. B.: Forecasting future land use for watershed assessment, J. Am. Water Resour. As., 35(3), 555-565, 1999.

Chaire en hydrologie statistique: HYFRAN - Hydrological Frequency Analysis, v. 1.1. INRS-ETE / HYDRO-QUÉBEC / ALCAN / CRSNG, 2002.

Cognard-Plancq, A.-L., Voltz, M., Didon-Lescot, J.-F., and Normand, M.: The role of forest cover on streamflow down subMediterranean mountain watersheds: a modelling approach, J. Hydrol., 254(1-4), 229-243, 2001.
Costa, M. H., Botta, A., and Cardille, J. A.: Effects of large-scale changes in land cover on the discharge of the Tocantins River, Southeastern Amazonia, J. Hydrol., 283(1-4), 206-217, 2003.

Crooks, S. and Davies, H.: Assessment of Land Use Change in the Thames Catchment and its Effect on the Flood Regime of the River, Phys. Chem. Earth (B), 26(7-8), 583-591, 2001.

Definens Imaging: eCognition: Online user guide, available at: http://www.definiens-imaging.com, 2001

Dolbec, J.-F., Rousseau, A. N., and Quilbé, R.: Développement d'un process de classification d'images satellitaires afin de détecter les changements d'occupation du sol sur le bassin versant de la rivière Chaudière pour la période 1970 à 2000 : Exemple de l'image Landsat-5 du 6 août 1987, Report N ${ }^{\circ} 802$, INRS-ETE, Québec, 2005.

Drogue, G., Pfister, L., Leviandier, T., El Idrissi, A., Iffly, J.-F., Matgen, P., Humbert, J., and Hoffmann, L.: Simulating the spatiotemporal variability of streamflow response to climate change scenarios in a mesoscale basin, J. Hydrol., 293(1-4), 255-269, 2004.

Dunn, S. M. and Mackay, R.: Spatial variation in evapotranspiration and the influence of land use on catchment hydrology, J. Hydrol., 171(1-2), 49-73, 1995.

Flato, G. M., Boer, G. J., Lee, W., McFarlane, N., Ramsden, D., and Weaver, A.: The CCCma global coupled model and its climate, Clim. Dynam., 16, 451-467, 2000.

Fohrer, N., Haverkamp, S., Eckhardt, K., and Frede, H.-G.: Hydrologic Response to land use changes on the catchment scale, Phys. Chem. Earth (B), 26(7-8), 577-582, 2001.

Fortin, J.-P., Turcotte, R., Massicotte, S., Moussa, R., Fitzback, J., and Villeneuve, J.-P.: A distributed watershed model compatible with remote sensing and GIS data, Part I: Description of the model, J. Hydrol. Eng., 6(2), 91-99, 2001a.

Fortin, J.-P., Turcotte, R., Massicotte, S., Moussa, R., Fitzback, J., and Villeneuve, J.-P.: A distributed watershed model compatible with remote sensing and GIS data, Part II: Application to the Chaudière watershed, J. Hydrol. Eng., 6(2), 100-108, 2001 b.

Fowler, H.J., Blenkinsop, S., and Tebaldi, C.: Review. Linking climate change modelling to impact studies: recent advances in downscaling techniques for hydrological modelling, Int. J. Climatol., 27, 1547-1578, 2007.

Gachon, P., St-Hilaire, A., Ouarda, T., Nguyen, V. T. V., Lin, C., Milton, J., Chaumont, D., Goldstein, J., Hessami, M., Nguyen, T. D., Selva, F., Nadeau, M., Roy, P., Parishkura, D., Major, D., Choux, M., and Bourque, A.: A first evaluation of the strength and weaknesses of statistical downscaling methods for simulating extremes over various regions of eastern Canada, Final report, Sub-component, Climate Change Action Fund (CCAF), Environment Canada, Montréal, Québec, Canada, 2005.

Gauthier, Y.: Rapport technique présenté dans le cadre de GIBSI, Rapport technique ${ }^{\circ}$ RT-462a, INRS-Eau, Sainte-Foy, Québec, 1996.

Johns, T. C., Gregory, J. M., Ingram, W. J., Johnson, C. E., Jones, A., Lowe, J. A., Mitchell, J. F. B., Roberts, D. L., Sexton, D. H. M., Stevenson, D. S., Tett, S. F. B., and Woodge, M. J.: Anthropogenic climate change for 1860 to 2100 simulated with the HadCM3 model under updated emissions scenarios, Hadley Centre Technical Note 22, The Hadley Centre for Climate Prediction and Research, The Met Office, Bracknell, UK, 2001.

Kite, G. W.: Application of a land class hydrological model to cli- 
matic change, Water Resour. Res., 29(7), 2377-2384, 1993.

Laprise, R.: Regional climate modelling, J. Comput. Phys., doi:10.1016/j.jcp.2006.10.024, in press, 2006.

Lavigne, M.-P., Rousseau, A. N., Turcotte, R., Laroche, A.-M., Fortin, J.-P., and Villeneuve, J.-P.: Validation and use of a distributed hydrological modeling system to predict short term effects of clear cutting on the hydrological regime of a watershed, Earth Interactions, 8(3), 1-19, 2004.

Matheussen, B., Kirschbaum, R. L., Goodman, I. A., O’Donnell, G. M., and Lettenmaier, D. P.: Effects of land cover change on streamflow in the interior Columbia River Basin (USA and Canada), Hydrol. Process., 14(5), 867-885, 2000.

Pielke, R. A. Sr.: Land use and climate change, Science, 310(5754), 1625-1626, 2005.

Quilbé, R., Rousseau, A. N., Duchemin, M., Poulin, A., Gangbazo, G., and Villeneuve, J.-P.: Selecting a calculation method to estimate sediment and nutrient loads in streams: application to the Beaurivage River (Québec, Canada), J. Hydrol., 326, 295-310, 2005.

Quilbé, R. and Rousseau, A. N.: GIBSI : An integrated modelling system for watershed management - Sample applications and current developments, Hydrol. Earth Syst. Sc., 11, 1785-1795, 2007.

Quilbé, R., Rousseau, A. N., Moquet, J.-S., Trinh, N. B., Dibike, Y. B., Gachon, P., and Chaumont, D.: Assessing the effect of climate change on river flow using general circulation models and hydrological modelling. Application to the Chaudière River (Québec, Canada), Can. Water Resour. J., in press, 2008.

Roeckner, E., Arpe, K., Bengtsson, L., Christoph, M., Claussen, M., Dümenil, L., Esch, M., Giorgetta, M., Schlese, U., and Schulzweida, U.: The atmospheric general circulation model ECHAM4: model description and simulation of present-day climate, 218, Max Planck Institut für Meteorology, 1996.

Rousseau, A. N., Mailhot, A., Turcotte, R., Duchemin, M., Blanchette, C., Roux, M., Etong, N., Dupont, J., and Villeneuve, J.-P.: GIBSI - An integrated modelling system prototype for river basin management, Hydrobiologia, 422/423, 465-475, 2000.
Scinocca, J. F. and McFarlane, N. A.: The variability of modeled tropical precipitation, J. Atmos. Sci., 61, 1993-2015, 2004.

Tong, S. T. Y. and Chen, W.: Modeling the relationship between land use and surface water quality, J. Environ. Manage., 66(4), 377-393, 2002.

Villeneuve, J.-P., Blanchette, C., Duchemin, M., Gagnon, J.-F., Mailhot, A., Rousseau, A. N., Roux, M., Tremblay, J.-F., and Turcotte, R.: Rapport Final du Projet GIBSI : Gestion de l'Eau des Bassins Versants à l'Aide d'un Système Informatisé. Mars 1998 : Tome 1., R-462, INRS-Eau, Sainte-Foy, 1998.

Wilby, R. L., Dawson, C. W., and Barrow, E. M.: SDSM - a decision support tool for the assessment of regional climate change impacts, Environ. Modell. Softw., 17(2), 145-157, 2002.

Wilby, R. L., Whitehead, P. G., Wade, A. J., Butterfield, D., Davis, R. J., and Watts, G.: Integrated modelling of climate change impacts on water resources and quality in a lowland catchment: River Kennet, UK, J. Hydrol. 330(1-2), 204-220, 2006.

Wischmeier, W. H. and Smith, D. D.: Predicting rainfall erosion losses - A guide to conservation planning, Agricultural Handbook No. 537, U.S. Department of Agriculture, Washington, D.C., 1978.

Wood A. W., E. P. Maurer, A. Kumar, and Lettenmaier, D.: Long-range experimental hydrologic forecasting for the eastern United States, J. Geophys. Res., 107(D20), 4429, doi:10.1029/2001JD000659, 2002.

$\mathrm{Xu}, \mathrm{C} .-\mathrm{Y}$.: Climate Change and Hydrologic Models: A Review of Existing Gaps and Recent Research Developments, Water Resour. Manage., 13(5), 369-382, 1999.

Yeo, I., Gordon, S. I., and Guldmann, J. M.: Optimizing patterns of land use to reduce peak runoff flow and nonpoint source pollution with an integrated hydrological and land-use model, Earth Interactions, 8(6), 1-20, 2004. 